\title{
80-lecie odsłonięcia pomnika Marii Skłodowskiej-Curie przed Instytutem Radowym
}

Przed 80 laty, 5 września 1935 roku, dokonano uroczystego odsłonięcia pomnika Marii Skłodowskiej-Curie na skwerze sąsiadującym z gmachem Instytutu Radowego przy ul. Wawelskiej w Warszawie.

Było to niemal dokładnie w rok po śmierci uczonej (zmarła 4 lipca 1934 r. w sanatorium Passy w Alpach). Inicjatorem wzniesienia pomnika byłówczesny Prezydent miasta
Warszawy - Stefan Starzyński. W uroczystości wzięli udział m.in.: małżonka Prezydenta Rzeczypospolitej Maria Mościcka, rodzeństwo Marii — dr Bronisława Dłuska, Helena Szalayowa i dr Józef Skłodowski, a także przedstawiciele rządu.

Autorką pomnika była Ludwika Nitschowa (1889-1989), uczennica m.in. Leona Wyczółkowskiego, późniejsza profesor warszawskiej Akademii Sztuk Pięknych, a zarazem żona

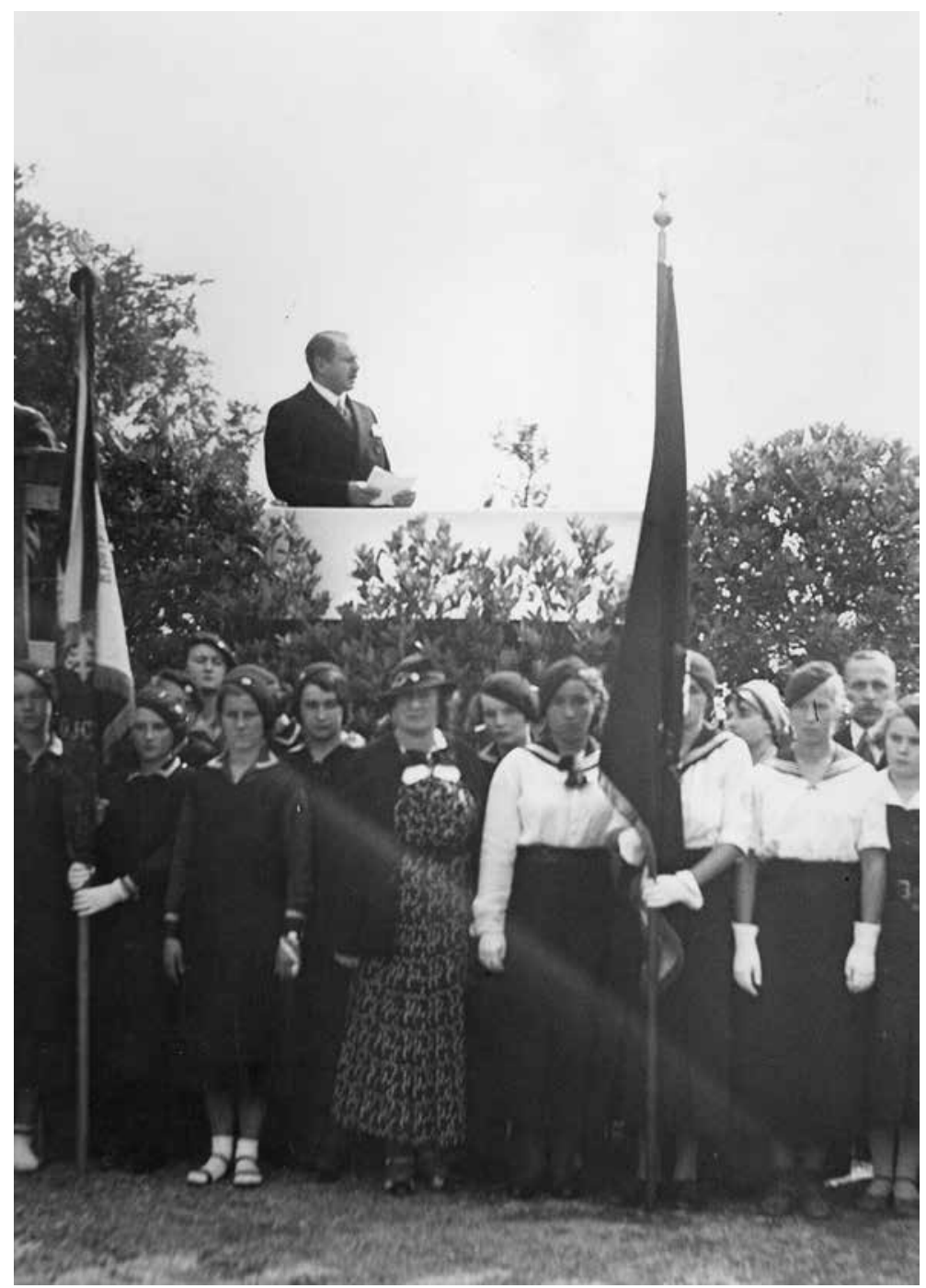

Przemówienie Prezydenta Warszawy Stefana Starzyńskiego podczas uroczystości 


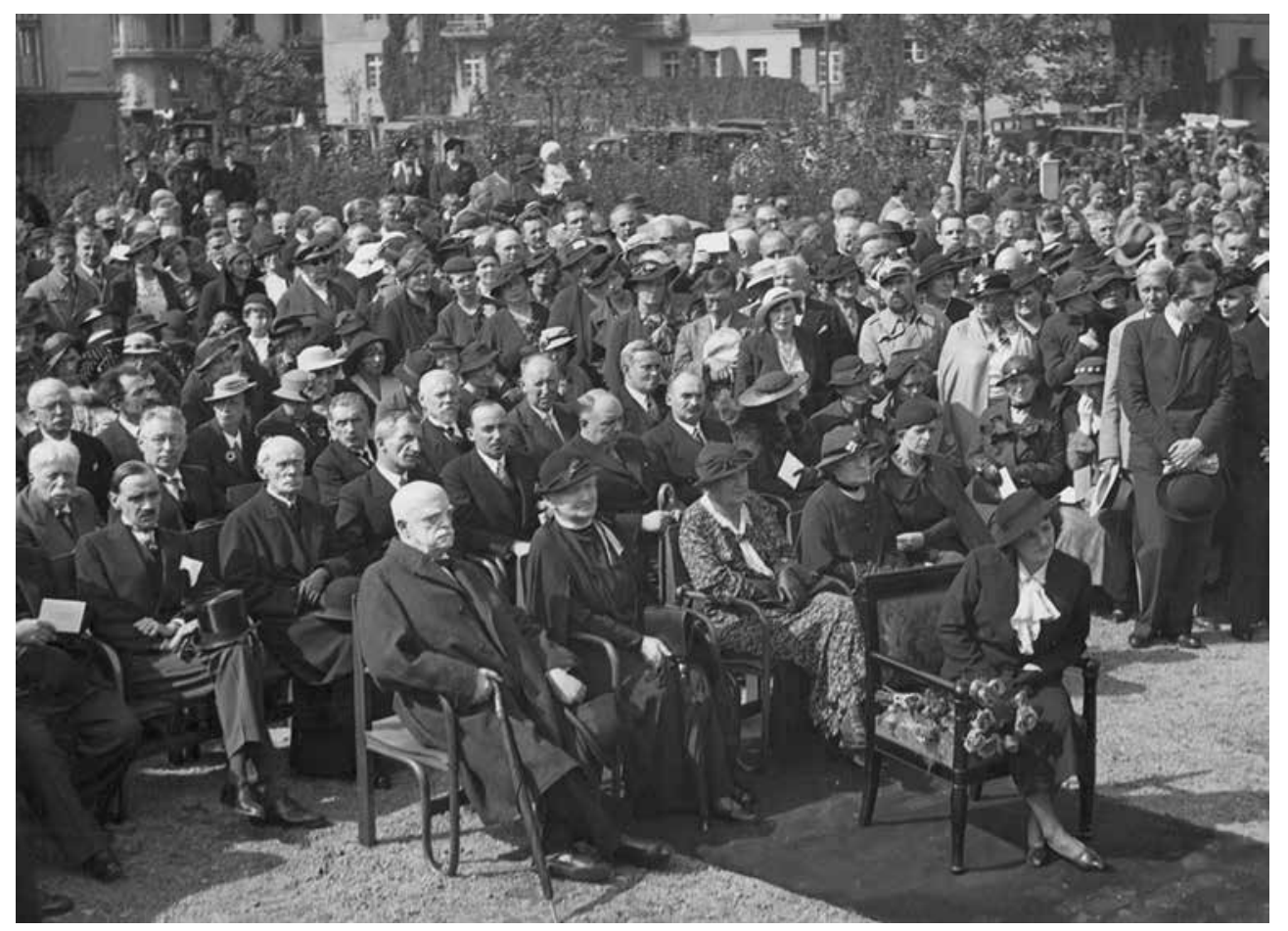

Fragment uroczystości. Widoczni m.in.: małżonka Prezydenta RP Maria Mościcka, rodzeństwo Marii Skłodowskiej-Curie: Józef Skłodowski, Bronisława Dłuska, Helena Szalayowa (w drugim rzędzie), wiceminister Bronisław Żongołłowicz, minister Juliusz Poniatowski, minister Wacław Jędrzejewicz, wiceminister Tadeusz Krychowski, wiceminister Eugeniusz Piestrzyński

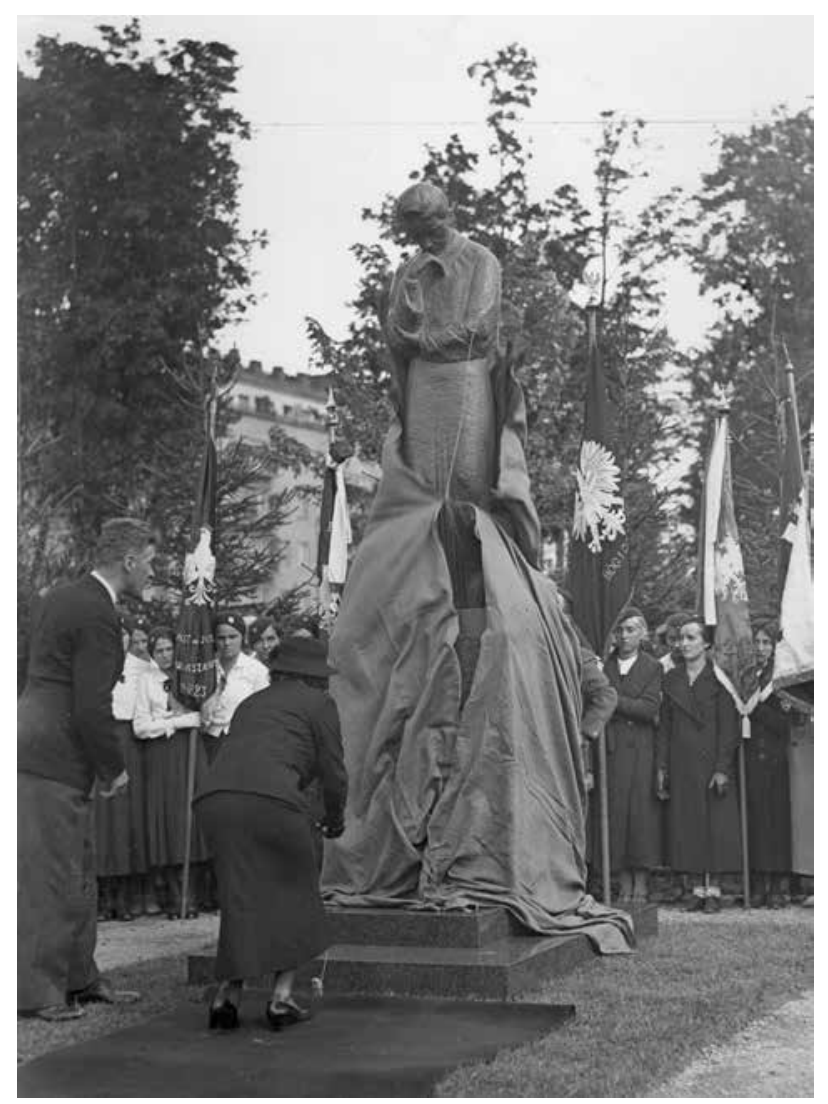

Moment odsłonięcia pomnika Marii Skłodowskiej-Curie przez Marię Mościcką 


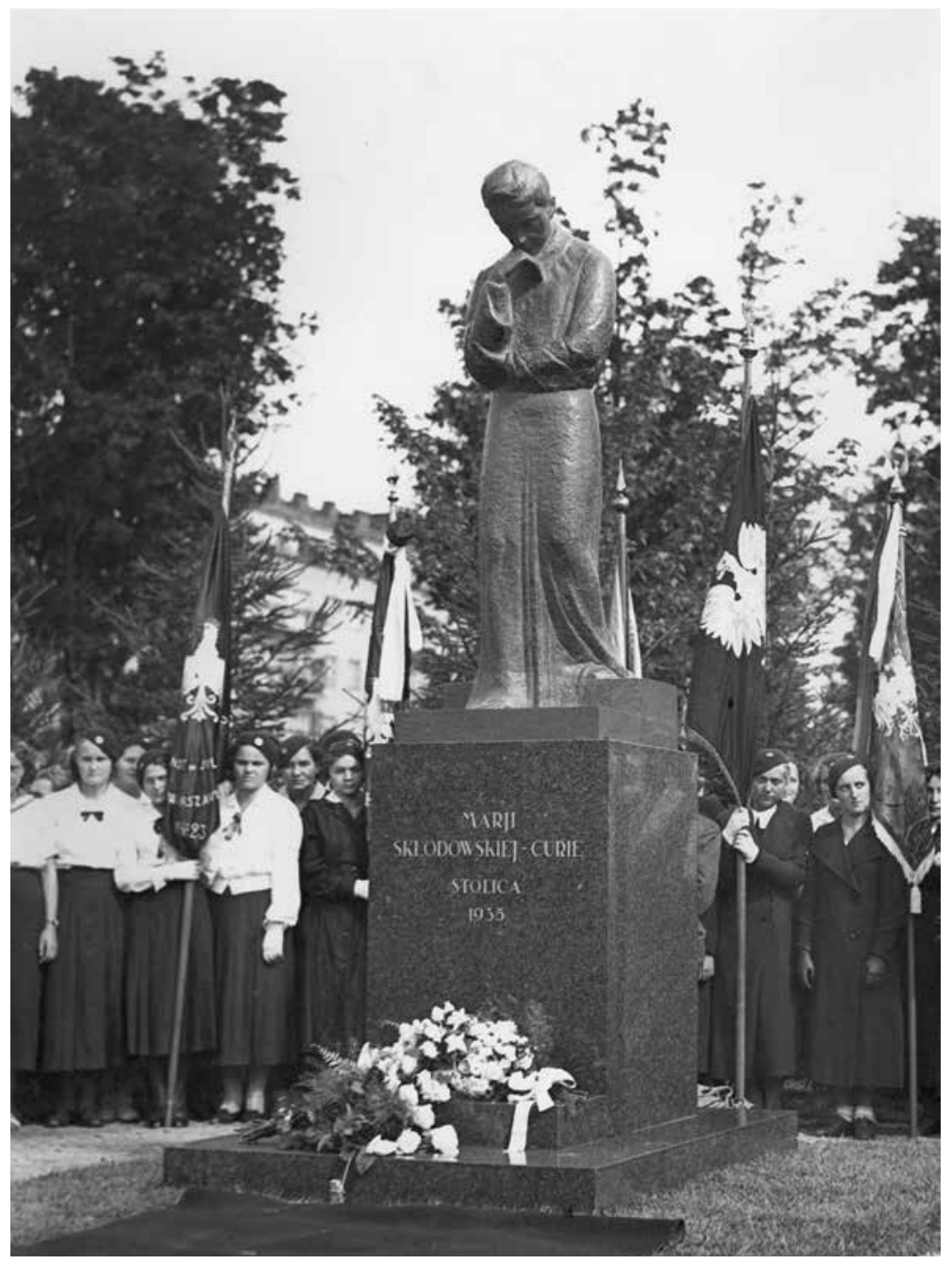

Pomnik Marii Skłodowskiej-Curie tuż po odsłonięciu i złożeniu kwiatów

Romana Nitscha, wybitnego bakteriologa i serologa, profesora Uniwersytetu Jagiellońskiego i Uniwersytetu Warszawskiego, prezesa Komitetu Instytutu Radowego do 1939 r. Drugą najbardziej znaną rzeźbą Ludwiki Nitschowej jest warszawska Syrenka, stojąca nad Wisłą, do której pozowała artystce Krystyna Krahelska, poetka, córka wojewody poleskiego, autorka m.in. popularnej piosenki Polski Walczącej pt.„Hej chłopcy, bagnet na broń” (zginęła w pierwszym dniu powstania warszawskiego jako sanitariuszka, opatrując pod ostrzałem rannego kolegę z oddziału).

Pierwotna wersja pomnika Marii Skłodowskiej-Curie, nagrodzona w 1932 r., była inna - ukazywała ją siedzącą, pochyloną nad książkami. Ostatecznie zrealizowano projekt przedstawiający uczoną stojącą (bądź kroczącą), w charak-

Zdjęcia: Narodowe Archiwum Cyfrowe terystycznej pozie zamyślenia i — jakby pozornej nieobecności. Nitschowa mogła dobrze podpatrzyć zachowania Marii Skłodowskiej, poznała ją bowiem i widywała podczas pobytu w Paryżu. Niektórzy twierdzą też, że pokazała w rzeźbie charakterystyczne odgięcie dłoni, spowodowane jakoby bolesnością na skutek oparzeń podczas badań substancji promieniotwórczych.

Posąg został odlany z brązu w czołowej warszawskiej firmie „Bracia Łopieńscy" i umieszczony na granitowym cokole. Przetrwał okupację, został jedynie uszkodzony kulami podczas powstania — nieopodal oprawcy z kolaboranckich oddziałów RONA dokonywali egzekucji pacjentów i personelu Instytutu Radowego oraz mieszkańców okolicznych domów. Ślady te pozostały do dziś.

\section{Prof. Edward Towpik}

Warszawski Uniwersytet Medyczny

Centrum Onkologii — Instytut im. Marii Skłodowskiej-Curie w Warszawie 